\title{
Chapter 2 \\ Determining Refugee Status \\ in the European Context: The Legal \\ and Institutional Framework
}

To illustrate the tensions between legal theory and administrative practice, it seems necessary to briefly sketch how highly regulated the asylum procedure is. Against this backdrop, the empirical findings will show that deciding upon asylum applications is more than "simply" applying the law to a case. The discussions in Parts II and III will highlight the variety of practices involved in putting this intricate legal framework into practice.

As a procedure of administrative law, the asylum procedure shares characteristics with other fields of public administration. Nevertheless, there are certain characteristics unique to the asylum procedure, among which is its legal framework. First, there is a strong link to international law and human rights as well as to the jurisprudence of higher courts (Bossuyt 2010). Whereas decisions regarding the entitlement to enter and remain in an EU member state are based on domestic privileges, decision making in the asylum procedure is based on international rights (Barnes and Mackey 2013:104). Additionally, the principles of surrogate protection when a state fails to provide national protection arise from international treaty obligations. Core treaties, such as the European Convention on Human Rights (ECHR) and the Geneva Convention Relating to the Status of Refugees, are living instruments "guided by dynamic or evolving interpretation in the light of social and political developments together with a liberal interpretation of rights and a narrow interpretation of restrictions" (ibid:103). In contrast to other fields of public administration, refugee and subsidiary protection status are declaratory rather than constitutive, implying that a claimant must be treated as a putative refugee who possesses certain rights (Barnes and Mackey 2013).

To understand the complexity and the transnational entanglement of the asylum procedure compared to most other street-level bureaucracies such as welfare services, it seems relevant to provide a brief overview of the legal framework accord-

The original version of this chapter was revised.

An erratum to this chapter can be found at https://doi.org/10.1007/978-3-319-63306-0_12 
ing to which decisions on international protection are made. As Thomas (2011:48) notes, the asylum procedure's "superficial simplicity conceals a mass of detailed, difficult, and very problematic factual and legal issues." In the following, some key elements of international refugee law and EU legislation on asylum are explained, followed by a short summary of legal and institutional developments in Austria. Finally, the structure and phases of the asylum procedure in Austria are outlined.

\subsection{International Refugee Law}

The right to seek and enjoy asylum is enshrined in different international legal instruments. First, article 14(1) of the Universal Declaration of Human Rights (UDHR) of 1948 prescribes that "everyone has the right to seek and to enjoy in other countries asylum from persecution." Since the UDHR was adopted as a nonbinding declaration, article 14 neither created an individual right to asylum nor a state-based obligation to provide it. However, due to the singularity of the provision on the universal level, it can be regarded as binding international law (Noll 2000:358). Moreover, the analysis of the drafting history and the later interpretation and implementation of constitutional asylum in different European states show that the right to asylum has been transformed into a right directly enforceable by individuals (Lambert et al. 2008). Going one step further, it can even be argued that in addition to the right to life, the right to asylum represents an existential right without which no other human right may be enjoyed (Chetail 2008). The preamble of the 1951 Refugee Convention states that the Convention was adopted "to assure refugees the widest possible exercise of these fundamental rights and freedoms," thereby referring to and reaffirming the principle of the UDHR.

The 1951 Convention Relating to the Status of Refugees and the 1967 Protocol Relating to the Status of Refugees constitute the benchmark for every domestic or regional regulation regarding asylum and refugee law (Zimmermann 2011:v). The states that ratified or acceded to the Convention agreed that the term "refugee" should apply to any person who is considered a refugee under earlier international agreements or who qualifies as a refugee under the UNHCR Statute. Originally, the application was limited to refugees who acquired such status "as a result of events occurring before 1 January 1951." States were also able to limit their obligations to refugees who had fled "events occurring in Europe" prior to that date. These limitations were expressly removed with the 1967 Protocol. The Convention identifies five relevant grounds of persecution and defines four key characteristics of Convention refugees that are still applied in today's refugee status determination processes. In article 1A(2), the 1951 Refugee Convention spells out that a refugee is someone who,

- "owing to well-founded fear of being persecuted for reasons of race, religion, nationality, membership of a particular social group or political opinion,

- is outside the country of his nationality and

- is unable or, owing to such fear, is unwilling to avail himself of the protection of that country 
- or who, not having a nationality and being outside the country of his former habitual residence as a result of such events, is unable or, owing to such fear, is unwilling to return to it."

Due to the specific focus of this book, I will not address the debate over social groups (Kirvan 1999; Rivas-Tiemann 2011) or explore the problems associated with the limited scope of the Convention (Williams 2008; McAdam 2012). However, one essential element of the Convention needs to be mentioned to understand the asylum procedure: the principle of non-refoulement, which represents a cornerstone of international protection. Article 33(1) of the 1951 Convention Relating to the Status of Refugees states that "no Contracting State shall expel or return ('refouler') a refugee in any manner whatsoever to the frontiers of territories where his life or freedom would be threatened on account of his race, religion, nationality, membership of a particular social group or political opinion." Protection against return to a country in which a person has reason to fear persecution and danger - the most essential component of refugee status and of asylum - has found expression in the principle of non-refoulement. However, the practices of national asylum administrations show the phenomenon of "indirect or chain refoulement" (Subramanya 2004; Taylor 2005). When states apply the "safe third country" concept, they must determine whether another country in which an asylum claimant can be expected to request asylum will accept responsibility for examining the asylum applications. Nevertheless, in practice, observations reveal that asylum claimants are refused admission and returned to a country through which they have passed, and then, without an examination of their claim, they are sent onwards either to their country of origin or to another clearly unsafe country. Thus, states adopt legal and administrative measures - such as expediting asylum procedures and shifting responsibility to other countries - that may result in placing refugees in situations that can ultimately lead to refoulement to their country of origin or to other countries in which their lives or freedom would be threatened. Therefore, national procedures require measures to ensure that respect for the principle of non-refoulement remains the guiding principle and ultimate objective of any refugee protection regime.

\subsection{EU Legislation on Asylum}

In addition to international law, supranational legal instruments define the character of refugee status determination. At the level of the European Union, the EU Charter of Fundamental Rights recognizes the right to asylum in article 18 (and the principle of non-refoulement in article 19), which can be traced back to article 14(1) of the 1948 UDHR. Proclaimed in 2000, the EU Charter has been legally binding since the Treaty of Lisbon entered into force in December 2009. Although there is debate among legal scholars over the material scope of the provision's application, on the basis of extensive analysis of this right's evolution in the EU Charter - including aspects of international and comparative regional law, the Charter's object and 
context, and its travaux préparatoires - it can be argued that the right to asylum in the Charter "is to be construed as a subjective and enforceable right of individuals to be granted asylum under the Union's law" rather than only as a procedural right to seek asylum (Gil-Bazo 2008:52). The right to asylum is thus enforceable as primary Union law, directly applicable within national legal orders without the need for further transposition; the Charter can also be directly invoked before national courts in the member states. Turning from law in the books to law in action (Pound 1910), however, state practice shows that the individual still has no right to be granted asylum since the right itself takes the form of a discretionary power (Goodwin-Gill and McAdam 2007: 414). The state has discretion as to whether to exercise its right and as to whom it will grant asylum or other protections and under which conditions such protections are to be enjoyed. The ideal of asylum as an obligation of states to accord lasting solutions, with or without a correlative right of the individual, thus continues to be resisted (ibid:415).

While an agenda for developing a Common European Asylum System (CEAS) was already established by the Tampere European Council in the key principles and aims of the Treaty of Amsterdam in October 1999, the entry into force of the Lisbon Treaty in 2009 eventually provided for the establishment of a "uniform status of asylum," "a uniform status of subsidiary protection," and a "common procedure" throughout the European Union. The treaty also made the EU Charter of Fundamental Rights legally binding. In June 2013, the European Parliament adopted several measures for a reformed CEAS, including common procedures, a basic set of rights created for asylum seekers arriving in the EU and a proposal to stop transfers to member states struggling to cope with the number of asylum seekers and related responsibilities. The European Asylum Support Office (EASO), established in 2010 and regarded as the most significant action taken by the Union to assist administrative cooperation (Peers 2011:375), is an EU agency that plays a key role in the development of the CEAS. The main purposes of the Office are to facilitate, coordinate and strengthen practical cooperation among member states; to provide operational support to member states subject to particular pressure on their asylum and reception systems; and to provide assistance regarding the policy and legislation of the Union in all areas having a direct or indirect impact on asylum (Regulation 439/2010). The EASO does not have any powers related to the decisions made by member states' asylum authorities on individual applications for international protection. The Office cooperates with the associated countries, other EU agencies such as Frontex, the Fundamental Rights Agency, and Europol as well as with UNHCR and members of courts and tribunals. The EASO contributes to the CEAS mainly by aiming at creating a common culture regarding asylum in member states, which is partially achieved through common training. The EASO Training Curriculum covers core aspects of the asylum procedure primarily for case officers but also for managers of asylum units, country of origin information (COI) researchers and other officers.

Among the many legal instruments in the field of asylum, six EU regulations and directives are particularly relevant to the asylum procedure (the first five of which were revised in 2013). The Asylum Procedures Directive (2005/85/EC, Directive 2013/32/EU) established common standards for safeguards and guarantees of access 
to a fair and efficient asylum procedure. According to the Directive, EU countries must ensure that applications are examined individually, objectively and impartially and that asylum claimants shall be entitled to remain in the country while their application is pending. The Reception Conditions Directive (2003/9/EC, 2013/33/ EU) requires member states to provide basic support needs - that is, a "dignified standard of living and comparable living conditions in all member states" - to asylum seekers while they are waiting on the assessment of their applications. The Qualification Directive (2004/83/EC, 2011/95/EU) addressed the lack of consistency in approaching the determination of refugee status by the different member states. Despite the adoption of this directive, there are still significant divergences in recognition rates between member states. The directive incorporates and interprets the refugee definition from the 1951 Convention and 1967 Protocol and provides for subsidiary protection. The Dublin Regulation (343/2003, 604/2013), which replaced the earlier Dublin Convention, established criteria and mechanisms for determining which member state is responsible for examining an asylum application lodged in one of the member states. This regulation established certain additions and amendments to the hierarchy of criteria for responsibility in the Convention along with an acceleration of the procedure for transferring asylum claimants between member states (Peers 2011:360). The Eurodac Regulation (2725/2000, 603/2013) was created to establish a system for comparing the fingerprints of asylum seekers. Aiming to facilitate the application of the Dublin II Regulation, it requires that fingerprints are taken from all asylum seekers over 14 years of age. The Return Directive (2008/115/EC) created common standards and procedures for returning thirdcountry nationals staying "illegally" in the territory of a member state (Art 2(1)).

One other European legal document needs to be addressed in this context. While there is no express provision relating to asylum within the $1950 \mathrm{ECHR}$, a substantial body of jurisprudence has emerged from the Convention organs, which set the standards for the rights of asylum seekers throughout Europe (Mole and Meredith 2010). Three of the most important articles in this document are article 3, prohibiting torture and inhuman or degrading treatment; article 8, encompassing the right to respect for family and private life; and article 13 , requiring a remedy for every victim of a violation of protected rights. Other articles particularly relevant to refugee status determination include article 2 (right to life), article 6 (right to a fair trial), article 10 (freedom of expression) and article 1 of Protocol No. 7 (concerning procedural safeguards relating to expulsion of aliens). The jurisprudence of the European Court of Human Rights (and its predecessor, the European Commission on Human Rights) has considerable precedential value, with a series of rulings in immigration and removal cases that impose important limitations on sovereign powers. Case law has had a particular impact on the development of the scope of non-refoulement beyond article 33 of the 1951 Convention by consistently reinforcing the absolute and non-negotiable nature of article 3 of the ECHR, which can be found in article 15 of the EU Qualification Directive, establishing subsidiary protection. Given this legal setting, officials must examine whether refoulement is admissible when the preconditions for granting asylum are not given. In the scope of this examination, among other things, they must investigate whether an expulsion would 
represent a "real risk" of violation of article 2 or article 3 of the ECHR. Decision makers thus need to be convinced that (i) the treatment feared either amounts to torture or can be considered inhuman or degrading and (ii) there are substantial grounds for believing that the individual will be exposed to such treatment when removed (Goodwin-Gill and McAdam 2007:310-11).

\subsection{The Austrian Context: Legal and Institutional Developments}

Having presented the international and supranational legal foundations of the refugee status determination procedure, I will now briefly outline the legal developments in Austria since the late twentieth century before providing a practice-oriented summary of the asylum procedure. Although I argue that the observed practices and identified dilemmas are similar in any Western bureaucracy because they are inherent to the asylum procedure as it is, particularly within the EU due to the same interand supranational standards, it still seems relevant to comment on the specific Austrian context since national socio-political and historical dimensions also play a role with regard to the practices of the contemporary asylum administration.

Before the introduction of the first Asylum Act ${ }^{1}$ in 1968, the Foreign Police Authority had to examine refugee status only as a preliminary question in a foreign police procedure. With the 1968 Asylum Act, the requirements and the lack of grounds for exclusion were determined by notification. Refugee status and permanent residency status were attached to the notification (Putzer 2011).

From the early 1960s to the mid-1980s, a politicization of immigration occurred in most Western European countries (Brochmann 1999). In Austria, this development implied a drastic change in decision-making patterns on immigration due to the emergence of new political parties and politicians fueling anti-immigrant sentiments and fear against immigrants from Eastern Europe. In this period, immigration control became not only more explicit but also more detailed. In 1985, a major impetus for reform of the legal framework was introduced by the Constitutional Supreme Court, annulling a provision of the Aliens Police Act (Fremdenpolizeigesetz) due to violation of article 8 of the ECHR protecting private and family life. While this impulse came from the judiciary and not from the political arena, it would become a lasting pattern, and judicial review has come to play an important role in immigration control legislation. Due to the rising number of asylum applications, a "three-track-model" was introduced in 1988. This model separated the procedures according to the purpose of entry (Bundesministerium für Inneres 2012:23). In the 1990s, a new immigration system emerged, and the Austrian government implemented new legislation on asylum, including the core principles of the 1990 Dublin Convention.

\footnotetext{
${ }^{1}$ Bundesgesetz vom 7. März 1968 über die Aufenthaltsberechtigung von Flüchtlingen im Sinne der Konvention über die Rechtsstellung der Flüchtlinge, BGB1. Nr. 55/1955.
} 
Since the parliamentarization of migration policy in the mid-1980s and the reconfiguration of migration policymaking in the late 1980s and early 1990s, "it was increasingly the political system - and its bureaucracy - that dominated the policymaking process and determined the contents of migration policies" (Kraler 2011). The number of asylum claimants had risen continuously since 1986, and nearly 90,000 people, mainly from Romania and Poland, applied for asylum in Austria between 1989 and 1992 (Böse et al. 2001). This new situation was addressed by new laws in 1991 regarding the asylum procedure (Asylgesetz 1991) and federal assistance for refugees (Bundesbetreuungsgesetz). On June 1, 1992, the FAO was established within the Ministry of the Interior. A special government commissioner for refugee and migration affairs, Willibald Pahr, stated in 1993 that Austria is "the first country in Europe that has embedded a comprehensive migration policy in its legal order" (Bauböck 1999:114 after Davy and Gächter 1993:155).

However, the reformed asylum policy was criticized not only as immoral but also as partly inefficient in its implementation. Among other reasons, the law was seen as unsatisfactory since the Administrative Supreme Court was receiving a flood of complaints questioning administrative decisions and practices in the field of asylum (ibid:121). In addition, under the new law, illegally entering the country became an alternative for refugees hoping not to be rejected at the border and to be tolerated once in the country. After numerous subsequent amendments, these and other concerns led to the adoption of a new asylum law only 6 years later in 1997 with the aim of keeping both the number of asylum claimants and the number of those granted asylum at the same low level as before while resolving problems in administrative implementation and conflicts with general legal principles. Austria joined the Schengen Accord in 1995, became a full member in 1997 and had until 1998 to abolish land borders with its Schengen neighbors.

With the Asylum Act (Asylgesetz 1997), which entered into force in 1998 and included several improvements to the procedure, the Austrian Independent Federal Asylum Review Board (UBAS) was introduced as an appeals authority not bound by instructions. Additionally, the new Act included a modification of the third country provision, which henceforth required a prognosis regarding the security in the other state (Putzer 2011). The right of residency for asylum claimants during the procedure was also introduced, with exceptions. This Act was amended (and tightened) several times; the amendment of 2003 led to structural changes in the procedure through the creation of the IRCs. In particular, these centers were responsible for both the first procedural steps and the consultation procedures following the Dublin II Regulation.

In 2005, the current Asylum Act (Asylgesetz 2005), which implemented the provisions of the EU Qualification Directive, entered into force as a part of the 2005 Aliens Law Package and entailed a further tightening of asylum law. The main objectives of the new Asylum Act included the creation of uniform professional country documentation unit (the COI Unit), the implementation of model case proceedings at the second instance of the asylum procedure, the timely establishment of the Dublin proceedings, new regulations regarding applicants' claims of traumatization, the creation of a legal basis concerning applicants' duties to cooperate, and the treatment of delinquent asylum claimants. 
The Asylum Act of 2005 has been fundamentally amended several times. In 2008, the UBAS was replaced by the Asylum Court. This modification implied that the Administrative Court was no longer responsible for appeals as a third instance; the only remaining appellate instance after the Asylum Court was the Constitutional Court. The Aliens Law Amendment Act of 2009 introduced, among other things, specific regulations concerning subsequent applications, provisions regarding asylum claimants and persons with international protection status who become delinquent, and the registration duties of asylum claimants during the procedure. Further modifications were introduced by the Foreigner Law Amendment Act in 2011, particularly concerning the provisions on legal advice in the asylum procedure (ibid). In 2014, a major change was implemented on the institutional level, incorporating the Federal Asylum Office into the newly established Federal Office for Immigration and Asylum and the Asylum Court into the new Federal Administrative Court.

As discussed above, the most recent tightening of the Asylum Law was implemented in 2016. The difficulties in handling the new situation of the so-called refugee crisis in 2015 were partly answered with legal solutions. In June 2016, an amendment to the Austrian asylum law entered into force; this amendment allowed the government to deny entry to refugees through an emergency regulation. In Europe, the ability to deny refugees the application for international protection at the border had thus far only existed in Hungary. With this new legislation, Austrian asylum law became among the strictest in Europe. The law defines an "emergency" as a threat to public policy or internal security. In such a situation, the only people usually allowed to apply for asylum are those who have close relatives in Austria (relating to article 8 ECHR), unaccompanied minors and women with small children, and those who would otherwise fear inhuman or degrading treatment or punishment (article 3 ECHR); all others are to be rejected and sent back to neighboring countries. A "state of emergency" is limited to 6 months but can be extended to up to 2 years. In connection with this regulation and implying an erosion of human rights, a highly controversial ceiling of 37,500 asylum applications was introduced but not reached in 2016; for 2017, a ceiling of 35,000 applications was established (derstandard 27.12.2016). If this number is reached, the government can make use of the emergency regulation. In addition, the Border Control Act was amended in 2016, reintroducing border controls (attacking the Schengen agreement) and fast procedures. In the planned registration centers, asylum claimants can be detained for up to $120 \mathrm{~h}$ to determine whether the claim must be accepted. The construction of a 370-meter fence at the border with Italy (Brenner Pass) was also heavily discussed.

Although legal reforms and amendments are constantly undertaken both at the EU and the national levels, they often tend to focus on the protection of the nationstate, its borders and security. By enacting migration management, states express their constant concern with ordering "the disorder that is human migration" (Mountz 2010:175). The introduction of emergency regulations, such as that of 2016 in Austria, illustrates the state's endeavor to manage the spontaneous movement of refugees. 
The reduction of bureaucratic obstacles and administrative costs in the sense of creating an effective and efficient administration as well as the expansion of regular immigration channels could represent a legal contribution toward improving the situation; however, Austria chose to move in the opposite direction (Hinterberger 2016). The current legal developments in Austria are criticized not only by churches, NGOs and the opposition but also by voices abroad. The German Huffington Post claimed that "a new Europe is being created in Austria. It's a Europe that is no longer cosmopolitan and progressive but closed and revisionist" (Klöckner 2016, own translation).

As this brief overview illustrates, the field of asylum is characterized by constant change. Modifications are made not only in the legal sphere (on the national and supranational level) but also with regard to the organizational-structural level (e.g., introduction of the IRC and the Asylum Court). These changes occur on the national level as well as on the level of the European Union. On both levels, numerous political and legal actions have been undertaken regarding the issue of asylum in recent decades, highlighting the volatility of the field of asylum.

However, with regard to the general migration policy in Austria, continuity prevailed. "Although the institutional set-up significantly changed in the 1990s, there are at the same time important institutional continuities and a remarkable stability in terms of the policy networks and policy communities involved" (Kraler 2011:53). Although continuity might be partly due to the fundamental role of the bureaucracy in framing and making migration policy, "it also can be interpreted as a reflection of a wider consensus on key principles - a consensus that to no small degree was influenced by the FPÖ's [Austrian Freedom Party] anti-immigrant populism" (ibid:52).

\subsubsection{How Can a Person be Granted International Protection in Austria?}

The meaning of relevant laws in practice for persons entering the asylum procedure and encountering the bureaucratic apparatus will be explained in the following short introduction to the Austrian asylum procedure. Although the asylum systems throughout Europe are generally similar to each other, there are differences between the specific national systems. This section introduces the main characteristics of the Austrian system in a general manner to provide an understanding of the asylum procedure as provided by national law.

Figure 2.1 illustrates the phases of the asylum procedure as currently executed in Austria. The relevant state institutions with which an asylum claimant will come into contact are the police and the FOIA (the former FAO), including the federal reception centers (the former IRCs). These institutions are subordinate to the Ministry of the Interior. The FOIA is an administrative body and the first instance for the determination of refugee status. Until the end of 2013, the Asylum Court was the court of appeal, representing the second and last instance, in which two judges 
The asylum application can be lodged with the police.i
After lodging an application, the asylum claimant is registered, interviewed and brought to one of the Federal Care Facilities ('Distribution centres') throughout Austria where $s /$ he lives (at least) for the duration of the admission procedure.

In the admission procedure the Federal Office for Immigration and Asylum (FOIA) ${ }^{\mathrm{ii}}$ assesses whether Austria or another EU member state is responsible for the procedure.

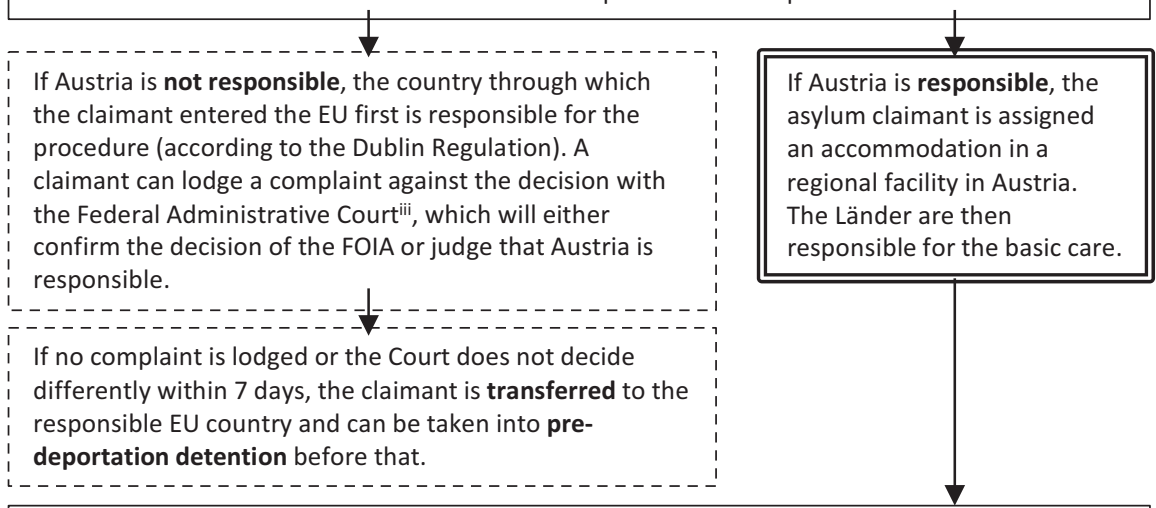

In the substantive procedure, the FOIA assesses whether the asylum claimant is persecuted or has to fear persecution in her/his country of origin.

The asylum claim is rejected if no flight reasons according to the GRC are found and the claimant does not have to fear a severe violation of human rights in the country of origin. The claimant can lodge a complaint with the Federal Administrative Court, and a complaint against the Court's decision with the Constitutional or Higher Administrative Courtiv.

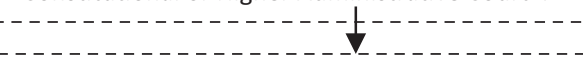

If no complaint is lodged with the Federal Administrative Court or the negative decision is confirmed, the claimant has to leave Austria. If s/he does not do that voluntarily, s/he can be deported to her/his country of origin. A complaint or revision with the with the Constitutional or Higher Administrative Court is possible; the deportation however cannot be prevented thereby.

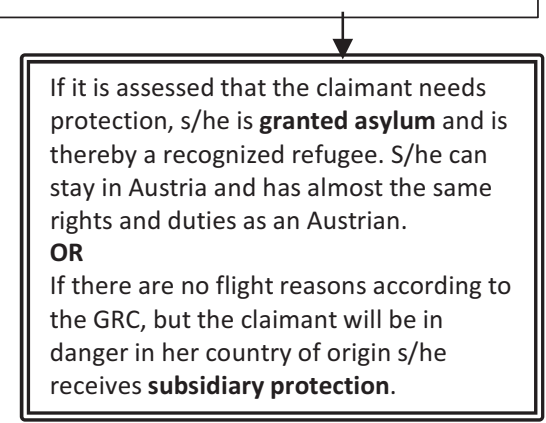

If neither flight reasons nor danger in the country of origin exist, the person may still be able to remain in Austria. Reasons can be that the person has been in Austria for many years already, is well integrated or has family members in Austria.

Fig. 2.1 The asylum procedure in Austria. (Source: Own production based on UNHCR 2015) (i) Until the amendment of 2015, asylum claimants were brought to the initial reception centers (IRCs)

(ii) Until 2014, the Federal Asylum Office was responsible for this assessment

(iii) Until 2014, the Asylum Court was responsible for this decision

(iv) The possibility of addressing the Higher Administrative Court in the asylum procedure was reintroduced in 2014 
decided in a council on a case. This was a special court that was subject to public law and had independent judges. As of January 1, 2014, an important institutional change was realized in the field of asylum in Austria: the Federal Asylum Office was incorporated into the new Federal Office for Immigration and Asylum and the Asylum Court was incorporated into the new Federal Administrative Court. In addition to these state institutions, various NGOs are engaged in supporting asylum claimants with legal and social aid.

\section{References}

Barnes, J., \& Mackey, A. (2013). The credo document. In C. A. F. M. Grütters, E. Guild, \& S. de Groot (Eds.), Assessment of credibility by judges in asylum cases in the EU. Oisterwijk: Wolf Legal Publishers.

Bauböck, R. (1999). Immigration control without integration policy - An Austrian dilemma. In G. Brochmann \& T. Hammar (Eds.), Mechanisms of immigration control: A comparative analysis of European regulation policies (pp. 97-134). Oxford/New York: Berg.

Böse, M., Haberfellner, R., \& Koldas, A. (2001). Mapping minorities and their media: The National Context - Austria. Vienna: Centre for Social Innovation. Retrieved from https://www. zsi.at/attach/MinoritiesMedia_AT2001.pdf

Bossuyt, M. (2010). Strasbourg et les demandeurs d'asile: des juges sur un terrain glissant. Bruxelles: Emile Bruylant.

Brochmann, G. (1999). The mechanisms of control. In G. Brochmann \& T. Hammar (Eds.), Mechanisms of immigration control: A comparative analysis of European regulation policies (pp. 1-28). Oxford/New York: Berg.

Bundesgesetz über die Gewährung von Asyl (Asylgesetz 1991) https://www.ris.bka.gv.at/ GeltendeFassung.wxe?Abfrage $=$ Bundesnormen $\&$ Gesetzesnummer $=10005800 \&$ Fassung Vom=1997-12-31

Bundesgesetz über die Gewährung von Asyl (Asylgesetz 1997 - AsylG) https://www.ris.bka. gv.at/GeltendeFassung.wxe?Abfrage=Bundesnormen $\&$ Gesetzesnummer $=10005997 \&$ Fassung Vom=1998-12-31

Bundesgesetz über die Gewährung von Asyl (Asylgesetz 2005 - AsylG 2005) https://www.ris.bka. gv.at/GeltendeFassung.wxe?Abfrage $=$ Bundesnormen $\&$ Gesetzesnummer $=20004240$

Bundesministerium für Inneres. (2012). 20 Jahre Bundesasylamt. Öffentliche Sicherheit, 5-6, 23.

Chetail, V. (2008). Foreword. Refugee Survey Quarterly, 27(3), 1-2. https://doi.org/10.1093/rsq/ hdn040.

Davy, U., \& Gächter, A. (1993). Zuwanderungsrecht und Zuwanderungspolitik in Österreich, Journal für Rechtspolitik, 155-174 (part I) and 257-268 (part II).

DerStandard. (2016). Asyl: Obergrenze für 2017 bereits zum Teil ausgeschöpft. http://derstandard. at/2000049881371/Asyl-Obergrenze-fuer-2017-bereits-zum-Teil-ausgeschoepft

Gil-Bazo, M.-T. (2008). The charter of fundamental rights of the European Union and the right to be granted asylum in the Union's Law. Refugee Survey Quarterly, 27(3), 33-52. https://doi. org/10.1093/rsq/hdn044.

Goodwin-Gill, G. S., \& McAdam, J. (2007). The refugee in international law. Oxford: Oxford UnivPress.

Hinterberger, K. F. (2016). Das Österreichische Asylgesetzänderungsgesetz 2016. In M. Bungenberg, T. Giegerich, \& T. Stein (Eds.), ZEuS-Sonderband: Asyl und Migration in Europa - rechtliche Herausforderungen und Perspektiven, 185. Retrieved from: https://ssrn.com/ abstract $=2885752$ 
Kirvan, S. (1999). Women and asylum: A particular social group. Feminist Legal Studies, 7(3), 333-342. https://doi.org/10.1023/A:1009270818460.

Klöckner, J. (2016, April 27). Österreich verschärft Asylrecht - 'Notstands'-Artikel gebilligt. The Huffington Post. Germany. Retrieved from http://videos.huffingtonpost.de/politik/ fluechtlingskrise-dieses-land-will-fluechtlinge-aufnehmen-aber-die-wollen-nicht-dort-leben id_5345892.html

Kraler, A. (2011). The case of Austria. In G. Zincone, R. Pennix, \& M. Borkert (Eds.), Migration policymaking in Europe: The dynamics of actors and contexts in past and present (1st ed., pp. 21-60). Amsterdam: Amsterdam University Press.

Lambert, H., Messineo, F., \& Tiedemann, P. (2008). Comparative perspectives of constitutional asylum in France, Italy, and Germany: Requiescat in pace? Refugee Survey Quarterly, 27(3), 16-32. https://doi.org/10.1093/rsq/hdn043.

McAdam, J. (2012). Climate change, forced migration, and international law. Oxford: Oxford University Press.

Mole, N., \& Meredith, C. (2010). Asylum and the European Convention on Human Rights (Human Rights Files No. 9). Strasbourg: Council of Europe Publishing.

Mountz, A. (2010). Seeking Asylum: Human smuggling and Bureaucracy at the border. Minneapolis: University of Minnesota Press.

Noll, G. (2000). Negotiating asylum: The EU acquis, extraterritorial protection and the common market of deflection. The Hague: Martinus Nijhoff Publishers.

Peers, S. (2011). EU justice and home affairs law. Oxford/New York: Oxford University Press.

Pound, R. (1910). Law in books and law in action. American Law Review, 44, 12.

Putzer, J. (2011). Asylrecht Leitfaden zum Asylgesetz 2005. Vienna: Manz.

Rivas-Tiemann, L. (2011). Asylum to a particular social group: New developments and its future for gang-violence. Tulsa Law Review, 47(2), 477-502.

Subramanya, N. (2004). Human rights and refugees. Geneva: APH Publishing.

Taylor, S. (2005). Nationality, refugee status and state protection: Explorations of the gap between man and citizen. Annandale: Federation Press.

Thomas, R. (2011). Administrative justice and asylum appeal: A study of tribunal adjudication. Oxford: Hart.

UN High Commissioner for Refugees (UNHCR). (2015). Flucht und Asyl in Österreich - die häufigsten Fragen und Antworten. Retrieved from http://www.unhcr.at/fileadmin/user_upload/ dokumente/02_unhcr/events/UNHCR_QA_2015_FINAL.pdf

Williams, A. (2008). Turning the tide: Recognizing climate change refugees in international law. Law \& Policy, 30(4), 502-529. https://doi.org/10.1111/j.1467-9930.2008.00290.x.

Zimmermann, A. (2011). The 1951 Convention relating to the status of refugees and its 1967 protocol: A commentary. Oxford: Oxford University Press.

Open Access This chapter is licensed under the terms of the Creative Commons Attribution 4.0 International License (http://creativecommons.org/licenses/by/4.0/), which permits use, sharing, adaptation, distribution and reproduction in any medium or format, as long as you give appropriate credit to the original author(s) and the source, provide a link to the Creative Commons license and indicate if changes were made.

The images or other third party material in this chapter are included in the chapter's Creative Commons license, unless indicated otherwise in a credit line to the material. If material is not included in the chapter's Creative Commons license and your intended use is not permitted by statutory regulation or exceeds the permitted use, you will need to obtain permission directly from the copyright holder.

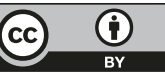

